\title{
The participle as a component of the verbal system in Biblical Hebrew
}

\author{
Jan Joosten \\ University of Oxford, Oxford, UK \\ jan.joosten@orinst.ox.ac.uk
}

\begin{abstract}
In Biblical Hebrew, the active participle has, as may be expected, a number of nominal and adjectival functions. However, it also, in certain contexts, exerts a verbal meaning. In the latter function, the participle is part of the verbal paradigm, expressing a range of nuances some of which-notably the expression of the "real present" - cannot be expressed by any other verbal form. The main verbal functions of the participle are exemplified in the paper. Also a diachronic trajectory of syntactic change is described leading from the "classical" Biblical Hebrew of the monarchic period (tenth to seventh centuries BCE) to early post-biblical Hebrew (first century в СE).
\end{abstract}

\section{Keywords}

participle - grammaticalization - diachronic paths - verbal semantics

The verbal system of Biblical Hebrew ( $\mathrm{BH})$ is notoriously enigmatic. A prefixconjugation (referred to as yiqtol) expressing nuances of irrealis modality: $t i$ $\underline{k} t \bar{o} \underline{b}$ "you will write," stands opposed to a suffix-conjugation (referred to as qatal) expressing, mostly, the perfect: $k \bar{t} \underline{t} a \underline{b}-t_{\bar{j}}$ "you have written." But when the conjunction $w$ "and" is added to the suffix-conjugation (a syntagm referred to as weqatal) its functions are those of the prefix-conjugation: wal̄oqah "and he will take." There is also a special short form of the prefix-conjugation (called the jussive), morphologically distinct only in some formal categories, expressing volition of the speaker: yahi "let him be," and with a special form of the conjunction (referred to as wayyiqtol) expressing the preterit: wayh $\bar{\imath}$ "and it was." Although all of this can be, and has been, explained in diachronical terms, 
none of it is easy to understand. Parts of this system nevertheless behave in a way that is typologically plausible. In the present paper, I will present one such area, the use of the participle in verbal clauses referring to processes contemporary with reference time. We will first look at the syntax as it is attested in the texts, and then take a look at the phenomena in diachronic perspective.

$\mathbf{1}$

The verbalized participle in Hebrew

1.1 Nominal and verbal uses of the participle

Hebrew, like many other languages, has a verbal form that encodes (or "transposes") the verbal idea into an adjective, that is: a form referring primarily to the carrier of the notion and secondarily to the notion itself: šomerer "one who guards", from š̄mar "to keep, to guard": 1

(1) Gen 4:9

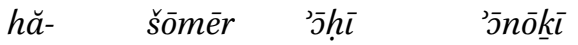

interrog. participle brother.my I

"Am I my brother's keeper?"

The participle has a variety of functions,

(2) Song 5:7

mașōūn̄i haš-šōmarìm has-sōbaboim

they found.me article-watch.PTCP.MP art.-make rounds.PTCP.MP

$b \bar{\jmath}{ }^{c} \mathrm{i} r$

in.the.city

The watchmen found me as they made their rounds in the city.

some of them purely nominal (haš-šōmarìm "the watchmen") and some of them "relative", nominalizing the verbal idea (has-sōba bīm "the makingrounds": "who were making rounds").

In prose, this form also occurs regularly as a predicate in clauses that to all intents and purposes are to be considered verbal:

1 There is also a "passive" participle, but in the present paper only the "active" participle will be referred to. The morphology of the participle is puzzling and interesting, but it will not occupy us here. What is at issue is a syntactic usage. 
(3) Gen 4:10

qōl damēe 's̄hịk̄ō șōăqīm 'ēla-y

voice bloods (of) brother.your cry out.PTCP.MP to-me

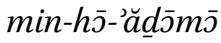

from-the-ground

The voice of your brother's blood is crying out to me from the ground!

The English present progressive is a bit ambiguous, perhaps, and may lead some to question the purely verbal function of the Hebrew participle. Languages that use a finite tense to express the real present show the point more clearly:

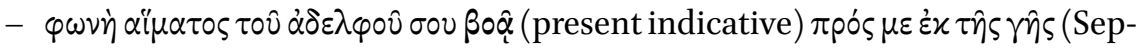
tuagint)

- vox sanguinis fratris tui clamat (present indicative) ad me de terra (Vulgate)

- la voix du sang de ton frère crie (present) de la terre jusqu'à moi (Louis Segond)

But even without this comparative evidence, the Hebrew clause is to be considered a verbal one, not a nominal one. The reason for this analysis is the function of the participle. In principle, the participle, even when it is a predicate, refers primarily to an entity:

(4) Gen 42:9

maraggalìm 'attem

participle you

You are spies!

However, in in a clause like that in Gen 4:10, the participle sheds this nominal meaning and refers purely to the verbal idea: the blood of Abel is not "a crying one", it is crying.

\subsection{The verbalized participle in the verbal paradigm}

In addition, participial clauses such as the one in Gen 4:10 are to be considered verbal because they occupy an important "slot" in the verbal paradigm. $\mathrm{BH}$, depending on the approach one takes, has between two and fourteen TAм forms (some of the fourteen are very rare). The principal forms were enumerated above:

- wayyiqtol expressing mainly the preterit "he killed" at some time in the past

- qatal expressing the perfect "he has killed, had killed"

- yiqtol expressing the future, the general present, repeated processes, odds and ends "will kill" 
- weqatal expressing approximately the same functions as yiqtol

- "volitive" forms (jussive, "cohortative," imperative)

What is obviously missing in this enumeration is a verbal form expressing the "real present", i.e. referring to processes going on at the moment of speech. This function is systematically expressed by means of the predicative participle.

\begin{tabular}{|c|c|c|c|}
\hline \multicolumn{2}{|r|}{ Indicative } & \multicolumn{2}{|c|}{ Modal } \\
\hline Past tense & non-tensed taxis & prospective & volitive \\
\hline wayyiqtol & $\begin{array}{cc}\text { anterior } & \text { contemporaneous } \\
\text { qatal } & \text { participle }\end{array}$ & yiqtol/weqatal & jussive etc. \\
\hline
\end{tabular}

(5) Gen $37: 15^{-16}$

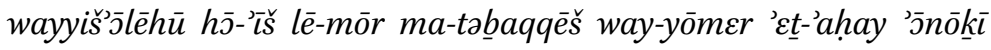

mabaqquēs

yiqtol I

participle

The man asked him, “What are you looking for?” He replied, "I'm looking for my brothers."

The yiqtol form can be used in reference to ongoing processes in questions, ${ }^{2}$ but in the positive answer only the participle can be used.

If the participle fills a slot in the verbal paradigm it ought to be considered part of that paradigm. The participle is "verbalized" in clauses like Gen 4:10.

\subsection{The functions of the verbalized participle}

The expression of the real present is not the only function regularly exerted by the verbalized, predicative, participle. A function rather closely resembling the real present is that of expressing attendant processes in a past or future time frame. The process is contemporary not with the moment of speaking, but with a reference time situated in the past or the future:

2 Interrogative sentences are inherently modal, which creates the possibility to use yiqtol in this way. In diachronic perspective, this usage is residual, see below. 
(6) Deut 4:11 wat-tiqrəbūn wat-ta'amd̄ūn taḥat hō-hōr wə-hō-hōr bōēèr b-̄̄-’ěš ‘ad-lēb haš-š̄̄mayim

You approached and stood at the foot of the mountain while the mountain was blazing up to the very heavens.

This again is a verbal function regularly expressed with the participle but hardly ever with other verbal forms.

In other usages, the verbalized participle expresses functions that can also be expressed with yiqtol. Both forms can refer to habitual processes:

(7) Exod 13:15

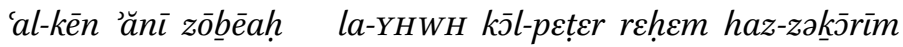

I participle

wa-kֵol-bakōr bōnay ' $\varepsilon \bar{p} d \varepsilon$

yiqtol

Therefore I sacrifice to the Lord every male that first opens the womb, but every firstborn of my sons I redeem.

Both forms are also used in reference to the immediate future. This partial overlap does not mean the two forms have the same meaning. Where they co-occur, the distinct function of each category is usually easy to determine:

(8) Deut 8:5

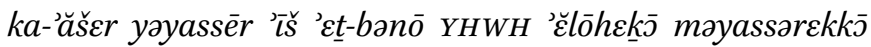

yiqtol participle-you

As a parent disciplines a child, so the LORD your God is disciplining you (NRSV).

The participle is indicative and refers to contemporaneous processes (contemporaneous with the reference time), yiqtol is more general, more modal and less closely tied to the reference time.

The participle also overlaps partially with the perfect, qatal (e.g. with stative verbs), although much less so than with yiqtol. As with yiqtol, the overlap does not contradict the unique and well-profiled role of the participle in the verbal paradigm. $^{3}$

3 For extensive exemplification of the verbal functions of the participle, see Joosten 1989, 2012. 


\subsection{The verbalized participle as an innovation}

Typological, comparative and inner-Hebrew considerations leave little doubt that the verbalized participle is a relatively recent phenomenon in the history of the language. Let us begin with Hebrew itself: in the earliest Hebrew texts, the predicative participle is very rare and never functions as a verbal expression of the real present or attendant circumstance (Notarius 2013). This absence may partly be due to accident: Archaic BH is represented by a small group of old poems, where the reference to ongoing processes is perhaps not expected. But a glance at other Semitic languages confirms that the use of the participle in these functions is not attested in early dialects. Ugaritic, a cognate NorthWest Semitic language used in literary and documentary texts of the fourteenth century BCE does not have it, nor Old Aramaic of the tenth to seventh centuries. Classical Arabic continues to manage without verbalized participle until today, using the cognate form of Hebrew yiqtol to express contemporaneity. Semitic languages further afield, such as Ethiopic and Akkadian, have nothing like the Hebrew verbalized participle. Aramaic, from the Imperial Aramaic phase onward, does use the participle in verbal clauses in a way that is similar to Hebrew. This suggests the verbalized participle may be an areal feature.

Typological studies have shown that innovations in verbal systems typically occur in two "slots," the present perfect and the "real present" (Kuryłowicz 1962, Bybee et al. 1994). The second of these slots is the one filled by the predicative participle in $\mathrm{B}$ H. Examples abound of typological parallels where new forms are integrated into the verbal system to express the "real present". One might think of the English present progressive, of course, but there are many examples in the Semitic languages too. In Arabic, the old present-future yaf'alu "he does" is replaced in its indicative functions by new-fangled forms such as bif'al "he does, is doing" and 'am bif'al "he's doing" in modern Palestinian dialects. Aramaic is even more interesting. In antiquity it shows up a development largely parallel to $\mathrm{BH}$, as was pointed out above. But in the modern dialects this originally participial form is attested only as an imperative or a modal form, being replaced by different types of new formations such as ili bi-praqa, "he is 'in'nomen actionis" (Cohen 1989).

These considerations leave little doubt that the verbalized participle was integrated into the verbal system shortly before the emergence of Hebrew as a literary dialect.

The same conclusion may be drawn from a study of Hebrew yiqtol. In Arabic, and probably in Ugaritic (which is unvocalized), the cognate of yiqtol is the regular expression of the real present and contemporaneity in the past. In $\mathrm{BH}$, 
yiqtol has almost entirely lost these functions. The expression of ongoing processes in questions is residual. Otherwise yiqtol expresses the general present and various modal nuances: predictive, obligative, optative, past-habitual. The functional profile of yiqtol may seem puzzling until one realizes that it is an expression of contemporaneous processes that lost its core functions. Martin Haspelmath (Haspelmath 1998) calls such forms "old presents". It lost these core functions to the participle.

\subsection{Developments of the verbalized participle within the biblical corpus}

When the verbalized participle comes into view, in early biblical prose, it already has a range of functions, as we saw in the first part of this paper. It expresses the real present and attendant circumstance, the immediate future and the habitual present. In light of the typological parallels, one may submit the participle was grammaticalized at first as a present and past progressive, and that the other functions are further developments. If this is what happened, the developments will have taken place before вн became the literary language documented in the Hebrew Bible. However, some of the later history of the verbalized participle can be documented within the Hebrew Bible and beyond. Three distinct phenomena will be discussed briefly.

2.1.1 The mere participle expressing verbal predication

In the "classical" prose of the Pentateuch and the older historical books, reflecting literary Hebrew of the monarchic period, the participle is verbal in regard to its function but it remains nominal in its morphology. Clauses with a participle superficially resemble nominal clauses. The use of the participle in almost every case requires the nominal or pronominal expression of the subject. In this respect, the participle differs from the finite verbal forms, which do not require a pronoun to represent the subject. One says hōlak "he went," yēlēk "he will go" (etc.), but hū hōlēk "he going" i.e. "he's going."4 This changes in later chronolects. In the "Late Biblical Hebrew" (LB H) attested in books of the Persian period, fifth and fourth centuries $\mathrm{BCE}$, the mere participle can express contemporaneous processes if the subject is a third person:

(9) Ezra 10:6

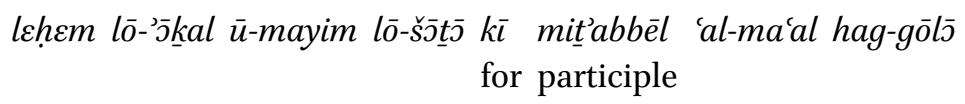

He did not eat bread or drink water, for he was mourning over the faithlessness of the exiles.

4 The phenomenon is sometimes described in terms of "pro-drop," but it is preferable to view it as a case of the zero-morpheme expressing the third person singular. 
The participle incorporates a reference to a third-person subject (a zero morpheme). ${ }^{5}$ There are several more examples of this syntax in the late books. In fact, the development seems to set in before the Persian period. It is found several times in Ezekiel, a book situated in the Babylonian period, sixth century BCE:

(10) Ezek 24:14

'ănīYHWH dibbartī b $\bar{\jmath}^{\prime} \bar{\jmath}$

participle fem.

I the LORD have spoken; it is coming.

The cases in Ezekiel may be the harbingers of a change that becomes more systematic in $\mathrm{LBH}$.

2.1.2 The participle expressing habitual processes in the past

While the participle regularly expresses concomitant processes in a past-tense context in classical Hebrew, it rarely occurs in reference to habitual processes. Iterative or habitual processes in a past-tense context are regularly expressed with yiqtol and weqatal in classical Hebrew. Again, this changes in LBH, where the participle is rather frequent in clauses expressing habit or regular iteration:

(11) Esther 3:2

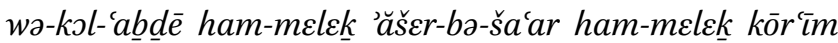

ū-mištahăwìm lo-hōmōn

part.

part.

And all the king's servants who were at the king's gate used to bow down and do obeisance to Haman.

In classical prose, the repeated processes would have been expressed with yiqtol and weqatal.

5 A parallel is found in Syriac, a late-Aramaic dialect (second century c.E. and onward). In Syriac the mere participle is the normal expression of the present-future. The paradigm is:

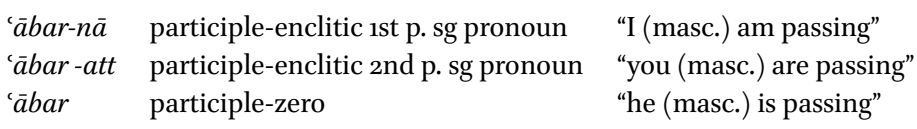
etc. 
2.1.3 Modal uses of the participle in post-biblical Hebrew

A usage not found in $\mathrm{BH}$ even in its latest strata, but attested in post-Biblical Hebrew is the modal one. In the sectarian texts from Qumran the examples are few and far between:

(12) Rule Scroll viI 2-3 w'm b'ḥd mn hkhnym hktwbym bspr dbr bḥmh wn'nš šnh ’ht

wmwbdl I npšw mn thrt rbym

and-participle

If anyone speaks angrily against one of the priests who are inscribed in the book, he is to be punished by reduced rations for one year and he will be separated ( $w+$ participle) from the pure meals of the general membership.

The passage illustrates at once the new modal function, and how the participle on its own, without pronominal subject, functions as a verb (see 2.1.1 above). In the Mishnah, a text from around $200 \mathrm{CE}$, where the participle is by far the most frequent verbal form, this modal, deontic, function is very frequent.

\section{Conclusion}

In much writing on the Biblical Hebrew verbal system, the participle is neglected. The ostensible symmetry between prefix- and suffix-conjugation has led Hebraists, again and again, to describe the entire system as a binary opposition: yiqtol is said to express imperfective aspect, qatal perfective aspect (e.g. Cook 2012). Much special pleading is needed to harmonize this neat theory with the data.

A more reasonable approach is to disregard the ostensible features of Hebrew morphology and accept that the verbal system is to some degree heterogeneous. The active participle started out as a verbal adjective, but at some point in the evolution of proto-Hebrew, it came to be incorporated into the verbal paradigm. The grammaticalization process by which a nominal form is integrated into the verbal system to express contemporaneity with the moment of speaking (or other reference times) finds typological parallels in the history of many other languages. Moreover, the diachronic development of participial functions continues along typologically well-understood lines, from "classical" to "late" biblical Hebrew and into post-biblical chronolects such as the language of the Dead Sea Scrolls and Mishnaic Hebrew. 
Due attention to the participle's verbal itinerary helps to understand the entire system. Since the verbal use of the participle includes the most typical instantiations of imperfective aspect the identification of yiqtol as an imperfective form (as in Cook 2012) becomes problematic. The yiqtol form needs to be recognized as an "old present" with some residual imperfective functions, but mostly expressing irrealis modality.

\section{References}

Andersen, Francis I. 1974. The Hebrew Verbless Clause in the Pentateuch, Nashville/New York: Abingdon.

Buth, Randall. 1999. Word Order in the Verbless Clause: A Generative-Functional Approach. in Cynthia L. Miller (ed.) The Verbless Clause in Biblical Hebrew. Linguistic Approaches, Winona Lake: Eisenbrauns. 79-107.

Bybee, Joan, Revere Perkins and William Pagliuca. 1994. The Evolution of Grammar: Tense, Aspect and Modality in the Languages of the World. Chicago: University of Chicago Press.

Cohen, David. 1989. L'aspect verbal. Paris: PUF.

Cook, John A. 2012. Time and the Biblical Hebrew Verb: The Expression of Tense, Aspect, and Modality in Biblical Hebrew. Winona Lake: Eisenbrauns.

Haspelmath, Martin. 1998. The Semantic Development of Old Presents. Diachronica 15. 29-62.

Joosten, Jan. 1989. The Predicative Participle in Biblical Hebrew. Zeitschrift für Althebraistik 2. 128-159.

Joosten, Jan. 2012. The Verbal System of Biblical Hebrew. A New Synthesis Elaborated on the Basis of Classical Prose. Jerusalem: Simor.

Kuryłowicz, Jerzy. 1962. L'apophonie en sémitique. La Haie: Mouton.

Notarius, Tania. 2013. The Verb in Archaic Biblical Poetry. Leiden: Brill. 